\title{
Nanobody cDNA Mock-Up in pHEN6c Plasmid Vector: Live Out
}

\author{
Tewodros Fentahun Jember \\ Department of Veterinary Biomedical Sciences, College of Veterinary Medicine and Animal Sciences, University of Gondar, \\ Gondar, Ethiopia \\ Email: tedyvet@gmail.com
}

How to cite this paper: Jember, T.F. (2021) Nanobody cDNA Mock-Up in pHEN6c Plasmid Vector: Live Out. American Journal of Molecular Biology, 11, 116-128. https://doi.org/10.4236/ajmb.2021.114010

Received: October 4, 2020

Accepted: October 11, 2021

Published: October 14, 2021

Copyright () 2021 by author(s) and Scientific Research Publishing Inc. This work is licensed under the Creative Commons Attribution International License (CC BY 4.0).

http://creativecommons.org/licenses/by/4.0/

\section{(c) (i) Open Access}

\begin{abstract}
Whenever there is no adequate DNA replication in vitro, there are alternatives strategies to insert a piece of DNA into a convenient replicon such as small plasmids and bacteriophages. These are called vectors or cloning vehicles. These days, there is a high demand to manufacture recombinant and nanobodies which are required in biomedical research and for therapeutic and diagnostic purposes. In order to do so, E. coli, insect cells, or mammalian cells have been used to express and purify protein for nanobody production. This paper explains the experimental trials on the cloning of the Nanobody cDNA mock-up in pHEN6c plasmid vector from the subcultured E. coli sample taken from the lab. The concentration and purity of DNA plasmid were evaluated by UV spectrophotometer and agarose gel electrophoresis following plasmid DNA Purification from $E$. coli by alkaline lysis. Based on this, the concentration of the isolated pHEN6c plasmid DNA was found $44.7 \mathrm{ng} / \mu \mathrm{l}$ or $0.0447 \mu \mathrm{g} / \mu \mathrm{l}$. Whereas, the purity at absorbance (A260/A280) was $0.893 / 0.501=1.78$. Moreover, its yield was $2.235 \mu \mathrm{g}$. In addition, its transformation efficiency was $21.68 \mu \mathrm{g} / \mu \mathrm{l}$. On the other hand, the molecular weight of the Nanobody and vector were 569 and 2717 respectively. Generally, most of the protocols used to clone a fragment of DNA, might not work very well with PCR products.
\end{abstract}

\section{Keywords}

Nanobody, Plasmid, cDNA, Therapeutics

\section{Introduction}

Cloning is the process of producing alike populations of genetic identicals that occurs in nature. It refers to processes used to create copies of DNA fragments. The term also refers to the production of multiple copies of a product. Whereas, a plasmid is a small, circular, double-stranded DNA molecule that is distinct 
from a cell's chromosomal DNA. It exists in bacterial cells, and they also occur in some eukaryotes. The genes carried on plasmids provide bacteria with genetic advantages, such as antibiotic resistance. Such technology allows to isolate any piece of DNA among millions of base pairs which make up the genome of an organism [1].

Restriction enzyme (RE) digestion plays a great role to generate compatible ends capable of being ligated together, furthermore, it is important to generate compatible ends from PCR products. Restriction enzymes can also be. Or such kind of conditions, one or several RE used to digest the DNA to have non-directional or directional insertion into the compatible plasmid [2].

The joining of two nucleic acid fragments through the action of an enzyme is called Ligation. It is a critical laboratory procedure in cloning of DNA to join DNA fragments together to have a recombinant DNA of foreign DNA fragment inserted into a plasmid. Then, phosphodiester bonds are formed between the 3'-hydroxyl of one DNA terminus with the 5'-phosphoryl of ends of DNA fragments. Bacterial cellular machinery naturally carries out DNA replication and protein synthesis that is why it is becoming a common dominant organism used for cloning a foreign DNA [3].

The Colony PCR is a common means to quickly screen plasmids containing a desired insert directly from bacterial colonies to eliminate the need to culture individual colonies and prepare plasmid DNA before analysis. Though, the availability of bacterial cell contents and culture media in colony PCR reactions reveals polymerase inhibition. To do so, a vigorous enzyme is required to perform colony PCR with better efficiency in many different bacterial strains. One-track DNA Polymerase, an optimized blend of Taq and Deep VentR ${ }^{\mathrm{TM}}$ DNA polymerases, formulated for robust yields at a lower optimization level. It results in OneTaq ideal for applications like colony PCR [4].

According to Jean-Louis [5], Electrophoresis is a technique used for separating and analyzing mixtures of charged molecules by incorporating Agarose which is used to make the gel after it has been melted in solution and allowed to solidify. The density of the agarose matrix depends on the concentration of the agarose solution. Different sized molecules can be separated effectively by choosing the appropriate concentration of it [6]. When an electric field is applied across the gel, negatively charged molecules move towards the anode. The rate of migration depends on the size of the molecules [6]. Hence, the objective of these experiments are to: isolate a plasmid PHEN6c from E. coli cell 1168; determine concentration of plasmid DNA; digest Nanobody gene and PHEN6c plasmid using restriction endonuclease; ligate using T4 DNA ligase; transform bacteria by making them competent and calculate transformation efficiency; screen colonies carrying Nanobody gene insert using PCR and determine the molecular weight of a DNA fragment using Agarose gel electrophoresis. The major objective of this work was to clone Nanobody cDNA into pHEN6c plasmid vector. 


\section{Plasmid Isolation (Alkaline Denaturation)}

\subsection{Materials and Methods}

\section{Procedure}

A single colony of $E$. coli 1168 from glycerol stock was inoculated into a $5 \mathrm{ml}$ of LB (supplemented with ampicillin) in a sterile $50 \mathrm{ml}$ tube and the second one without ampicillin (negative). The tubes incubated at $37^{\circ} \mathrm{C}$ overnight while shaking at $250 \mathrm{rpm}$. The culture was harvested as pellet in $2 \mathrm{ml}$ of an overnight recombinant $E$. coli culture by centrifugation and transferred the appropriate volume of the recombinant $E$. coli culture to a Microcentrifuge tube and cells were plleted at $\geq 12,000$ for a minute. Then the supernatant was discarded. Bacterial pellet was completely resuspended with $200 \mu \mathrm{l}$ of the resuspension solution (10 mm EDTA, which breaks the bacterial cell wall, $50 \mathrm{~mm}$ Tris- $\mathrm{HCl}$, water and $100 \mu \mathrm{g} / \mathrm{ml}$ RNase which destroys RNA). Vortexes thoroughly to resuspend the cells until homogeneous. The resuspended cells were lysed by adding $200 \mu \mathrm{l}$ of the Lysis Solution $(0.2 \mathrm{M} \mathrm{NaOH}, 1 \% \mathrm{w} / \mathrm{v}$ SDS), then mixed the contents by gentle inversion until the mixture became clear and viscous. Cell debris was precipitated the by adding $350 \mu \mathrm{l}$ of the Neutralization/Binding Solution. Gently invert the tube several times. Pellet the cell debris by centrifuging at $\geq 12,000 \times$ for maximum speed for 10 minutes. A GenElute Miniprep Binding Column was inserted into a provided Microcentrifuge tube, $500 \mu$ of the Column Preparation Solution was added to each miniprep column and centrifuged at $\geq 12,000 \mathrm{x} g$ for 1 minute. Then the flow-through liquid was discarded. The cleared lysate was transferred and centrifuged at $\geq 12,000 \times \mathrm{g}$ for 1 minute. Then the flow-through liquid was discarded. $750 \mu \mathrm{l}$ of the diluted Wash Solution was added to the column and centrifuged at $\geq 12,000 \mathrm{x} g$ for 1 minute. The column was transferred to a fresh collection tube and then $100 \mu$ of Elution Solution $\left(\mathrm{dH}_{2} \mathrm{O}\right)$ was added to the column. Finally, it was centrifuged at $\geq 12,000$ for a minute [7] [8].

\subsection{Determination of Plasmid DNA Concentration}

Procedure: A $1 \mathrm{ml}$ of a 1/100 dilution of the DNA sample was prepared in $\mathrm{ddH}_{2} \mathrm{O}$ in an Eppendorf tube. The spectrophotometer was turned on and waited for $15 \mathrm{~min}$. The wavelength was set at $260 \mathrm{~nm}$. Set reference (zero) with distilled $\mathrm{H}_{2} \mathrm{O}$ and sample was dissolved. Diluted DNA sample was transferred into a quartz cuvette and the absorbance was read. Repeated the measurement at 280 $\mathrm{nm}$.

\section{Restriction Endonuclease Digestion of Nanobody Gene and Phen6c Plasmid}

\section{Materials and Methods}

Procedures: Digestion of Vector (Plasmid): Due to low concentration, we have used plasmid $210 \mathrm{ng} / \mu \mathrm{g}$ and then $47.5 \mu \mathrm{l}$ was added with $5 \mu \mathrm{l}$ buffer-O (Fermentas), $1 \mu \mathrm{l}$ Eco91I (Fermentas, 10 units/ $\mu \mathrm{l}$ ) and $1 \mu \mathrm{l}$ PstI (Fermentas, 10 
units/ $\mu \mathrm{l}$ ), $210 \mathrm{ng}=1 \mu \mathrm{l}$, then what will be for $10 \mu \mathrm{g}$, so, $\mathrm{X}=47.5 \mu \mathrm{l}$. Hence, 47.5 $\mu \mathrm{l}$ plamid $+5 \mu \mathrm{l}$ buffer-O $+1 \mu \mathrm{l}$ Eco91I $+1 \mu \mathrm{l}$ PstI $=54.5 \mu \mathrm{l}$ used; then it was allowed to be digested at $37^{\circ} \mathrm{C}$ overnight. On the next day, it was heat at $65^{\circ} \mathrm{C}$ for $20 \mathrm{~min}$; the digested vector was cleaned by using PCR clean up kit-GenElute. PCR fragment was Eluted with $50 \mu$ distilled $\mathrm{H}_{2} \mathrm{O}$. The concentration and purity was measured on Nanodrop ${ }^{\mathrm{TM}}[9]$.

\section{Ligation}

Procedure: Into a fresh sterile $1.5 \mathrm{ml}$ eppendorf tube, $50 \mathrm{ng}$ vector, $50 \mathrm{ng}$ PCR fragment, $2 \mu \mathrm{l}$ ligation buffer and $1 \mu \mathrm{l} 44$ DNA ligase ( 5 units/ $\mu$ l) were added. Reaction mixture was topped by $20 \mu \mathrm{l}$ with distilled $\mathrm{H}_{2} \mathrm{O}$ and which means, 0.23 $\mu \mathrm{l}$ was used. Finally, the tube was incubated for $1 \mathrm{~h}$ at room temperature.

\section{Transformation}

\section{Generation of $\mathrm{CaCl}_{2}$ Competent E. coli Cells}

Procedure: Based on Watson et al. [10] and Steven et al. [8]; five milliliters of LB (without antibiotics) was prepared in one sterile $50 \mathrm{ml}$ tube. The tube was inoculated with a single colony of $E$. coli WK403 from a fresh plate then, the tube was incubated at $37^{\circ} \mathrm{C}$, shaking vigorously at $230 \mathrm{rpm}$ overnight. The next day $20 \mathrm{ml} \mathrm{LB}$ was inoculated with $0.2 \mathrm{ml}$ of the overnight culture. Allowed to grow to early log phase, OD600 $\mathrm{nm}$ in cuvette $=0.2(-0.4 \mathrm{max})$ (90 minutes). After growth, the $50 \mathrm{ml}$ tube containing the cell culture was put on ice for 10 minutes. Cells were pelleted for $7 \mathrm{~min}$ at $3000 \mathrm{rpm}$ in an Eppendorf centrifuge at $4^{\circ} \mathrm{C}$. The supernatant was poured and gently re-suspended pellet in $10 \mathrm{ml}$ sterile ice cold $0.1 \mathrm{M} \mathrm{MgCl}_{2}$. Centrifuged $7 \mathrm{~min} 3000 \mathrm{rpm}$ in $4^{\circ} \mathrm{C}$ Eppendorf centrifuge. The supernatant was Poured and gently re-suspended pellet in $10 \mathrm{ml}$ sterile ice cold $0.1 \mathrm{M} \mathrm{CaCl}_{2}$. Incubated at least $30 \mathrm{~min}$ on ice for an hour. Centrifuged for 7 min $3000 \mathrm{rpm}$ in $4^{\circ} \mathrm{C}$ eppendorf centrifuge. Supernatant was removed and $2 \mathrm{ml}$ sterile ice cold $0.1 \mathrm{M} \mathrm{CaCl}_{2}$ on the bacteria as well as $0.3 \mathrm{ml}$ sterile ice cold $100 \%$ glycerol. Incubated for $30 \mathrm{~min}$ on ice. Then, $100 \mu \mathrm{l}$ cell suspensions were aliquot in three $1.5 \mathrm{ml}$ eppendorf tubes labelled T1, T2 and T3; and allowed to keep tubes on ice for $30 \mathrm{~min}$.

According to the concentration we had $=24.4 \mathrm{ng} / \mu \mathrm{l} .24 .4 \mathrm{ng}=1 \mu \mathrm{l}, 50 \mathrm{ng}=$ $\mathrm{X}$ ? $\mathrm{X}=50 \mathrm{ng} \times 1 \mu \mathrm{l} / 24.4 \mathrm{ng}=2.05 \mu \mathrm{l}$. The following mix was prepared: $\mathrm{DdH}_{2} \mathrm{O}$ $=12.9 \mu \mathrm{l}$, Plasmid $=2 \mu \mathrm{l}, \mathrm{cDNA}=2.1 \mu \mathrm{l}$, Ligase Buffer $=2 \mu \mathrm{l}$ and T4 Ligase $=1$ $\mu \mathrm{l}$.

\section{Heat-Shock Transformation}

Procedure: Three tubes $(1-3)$ of the $100 \mu$ cell aliquots were prepared: in Tube 1 (Positive control) $0.5 \mu \mathrm{g}(2.5 \mu \mathrm{l})$ purified intact plasmid DNA was added. On the other hand in Tube 2: $10 \mu$ of unpurified ligation was added, however, in Tube 3 no DNA was added. Tubes were incubated on ice for 30 minutes. Then, tubes were placed in a warm bath at $42^{\circ} \mathrm{C}$ for exactly 90 seconds. Tubes were put 
back on ice for 2 minutes. Furthermore, $1.5 \mathrm{ml}$ of LB medium was added to each tube and place them in an incubator at $37^{\circ} \mathrm{C}$ for 45 minutes. Cells were plated on LB agar containing ampicillin. Using micropipette, $100 \mu \mathrm{l}$ of each of transformation preparation was dispensed on three LB-AMP agar plates. Then, they were incubated at $37^{\circ} \mathrm{C}$ upside down overnight.

On the next day (after $19 \mathrm{hrs),} \mathrm{Growth} \mathrm{on} \mathrm{the} \mathrm{positive} \mathrm{control} \mathrm{(plate} \mathrm{land} \mathrm{the}$ sample plate 2), however, there was no growth of the colony on plate 3 (negative control); the number of colonies were counted; and the average number of colonies was taken for calculating efficiency of transformation. The plates transformed with the ligate were spared for colony PCR. The transformation efficiency was calculated.

\section{PCR}

Procedure: PCR master mix was made for total of 6 tubes in a single $1.5 \mathrm{ml}$ eppendorf. The master mix made as indicated below for one (1) PCR tube; calculate for 6 PCR tubes.

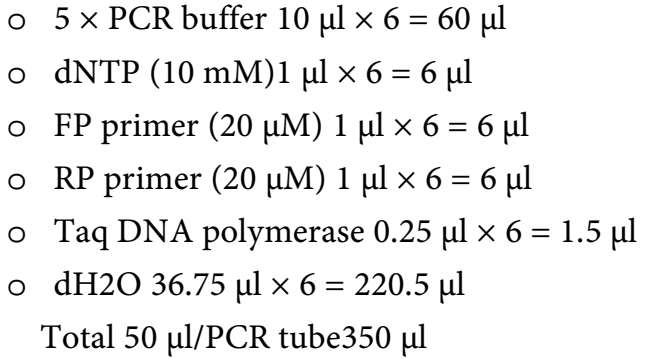

Three colonies are randomly picked using a sterile pipette tip from a test plate and one from each of the control plates and dipped in separate tubes with a $50 \mu \mathrm{l}$ master mix. The third tube was used as a negative control since no colony was added. The tips were left in the tubes for 10 minutes and ticked away with care. The tubes were then closed and placed in the thermal cycler Program: SHORT57 as described bellow:

\begin{tabular}{|c|c|c|c|}
\hline \multirow[t]{6}{*}{ Programme: } & Pre-cycle & $95^{\circ} \mathrm{C}$ & 3 mins \\
\hline & 28 cycle & $94^{\circ} \mathrm{C}$ & $30 \mathrm{sec}$ \\
\hline & & $57^{\circ} \mathrm{C}$ & $30 \mathrm{sec}$ \\
\hline & & $72^{\circ} \mathrm{C}$ & $45 \mathrm{sec}$ \\
\hline & Post-cycle & $2^{\circ} \mathrm{C}$ & 10 mins \\
\hline & & $4^{\circ} \mathrm{C}$ & taken out after about two hours \\
\hline
\end{tabular}

\section{Analysis of Pcr Product by Agarose Gel Electrophoresis}

Procedure: The gloves were put on and then molten $1 \%(\mathrm{w} / \mathrm{v})$ agarose gel was Poured in $1 x T B E$ (kept in the oven at $60^{\circ} \mathrm{C}$ ) in a tray; $30 \mu$ l ethidium bromide was add at $10 \mathrm{mg} / \mathrm{ml}$ to molten gel and mix by stirring with the pipette tip a comb was put with the teeth pointing downwards on the gel holder. All air bub- 
bles were checked and removed using clean pipette tip. The gel was solidified within 20 minutes and made ready. Solid gel was placed in an electrophoresis buffer tank with tray; 1xTBE electrophoresis buffer poured to completely cover the gel. $16.7 \mu \mathrm{l}$ of each PCR product was mixed (and negative control) with $3.3 \mu \mathrm{l}$ loading buffer and loaded $15 \mu$ from slot number two onwards. Negative control loaded into the last slot. Then $5 \mu \mathrm{l}$ smart ladders (marker) were loaded on the first slot. Lid was put on the buffer tank, the positive (red) and negative (black) electrodes were connected. The voltage was set at $125 \mathrm{~V}$ for 40 minutes. The power supply was shut down as soon as finishing; the gel was carefully handled and taken to the room where UV light was found, finally the gel was put on the UV light booth. The machine was on and bands of fluorescence were visible to the eye. The image screen and the printer were switched on. The molecular weight of nanobody cDNA was determined [8] [11].

\section{Result}

\subsection{Plasmid Isolation and Determination of Its Concentration and Purity}

After isolation of pHEN6c plasmid DNA, concentration was determination by spectrophotometry and $44.7 \mathrm{ng} / \mu \mathrm{l}$ or $0.0447 \mu \mathrm{g} / \mu \mathrm{l}$ was found (Figure 1). Furthermore, its purity was assessed by analyzing the ratio of absorbance at $260 \mathrm{~nm}$ to $280 \mathrm{~nm}(\mathrm{~A} 260 / \mathrm{A} 280)$. Thus, DNA purity $=\mathrm{A} 260 / \mathrm{A} 280=0.893 / 0.501=1.78$ was found. Whereas, regarding its yield, $0.0447 \mu \mathrm{g} / \mu \mathrm{l} \mathrm{X} 50 \mu \mathrm{l}=2.235 \mu \mathrm{g}$ (Figure $1)$.

\subsection{Restriction Endonuclease and Transformation Efficiency}

\begin{tabular}{cc}
\hline Measure & \\
\hline Concentration $(\mathrm{ng} / \mu \mathrm{l})$ & 107 \\
Purity & 1.79 \\
\hline
\end{tabular}

Similarly, the concentration of digested CDNA and its purity were $107.0 \mathrm{ng}$ or $0.107 \mu \mathrm{g} / \mu \mathrm{l}$ and 1.79 at A260/A280 respectively. Meanwhile the yield of DNA in $50 \mu \mathrm{L}$ was $0.107 \mu \mathrm{g} / \mu \mathrm{l}$ X $50 \mu \mathrm{l}=5.35 \mu \mathrm{g}$.

\subsection{Determination of Molecular Weight of Plasmid DNA (Vector)}

For molecular weight determination of the vector which was was run on $1 \%$ agarose gel and following bands were obtained.

\subsection{Transformation Efficiency}

According to a protocol of Brown [12] and Steven et al. [8] and since we used 24.4 $\mathrm{ng} / \mu \mathrm{l}$ intact plamid DNA and took $50 \mathrm{ng}$ of its concentration $(=2 \mu \mathrm{l})$ which was added to $100 \mu \mathrm{l}$ aliquot cells. We also add $1000 \mu \mathrm{LB}$ buffer solution. Then concentration of DNA in the solution $=(50 \mathrm{ng} / 1102) \mathrm{ng} / \mu \mathrm{l} \approx 0.045 \mu \mathrm{g} / \mu \mathrm{l}$. After, 100 


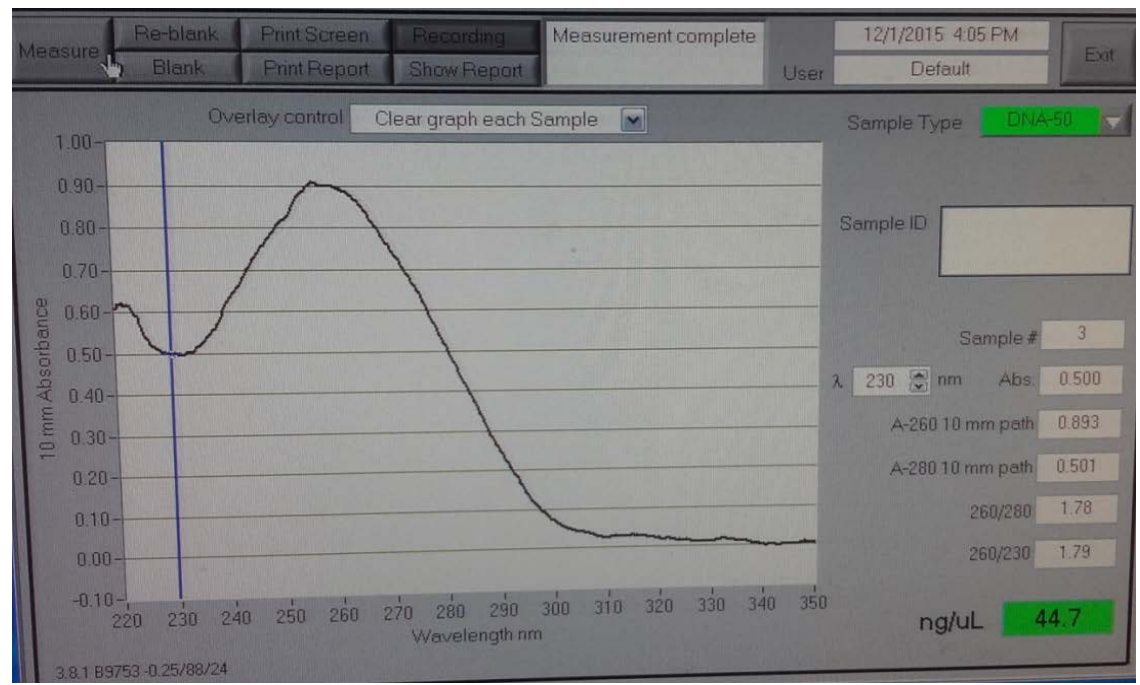

(a)

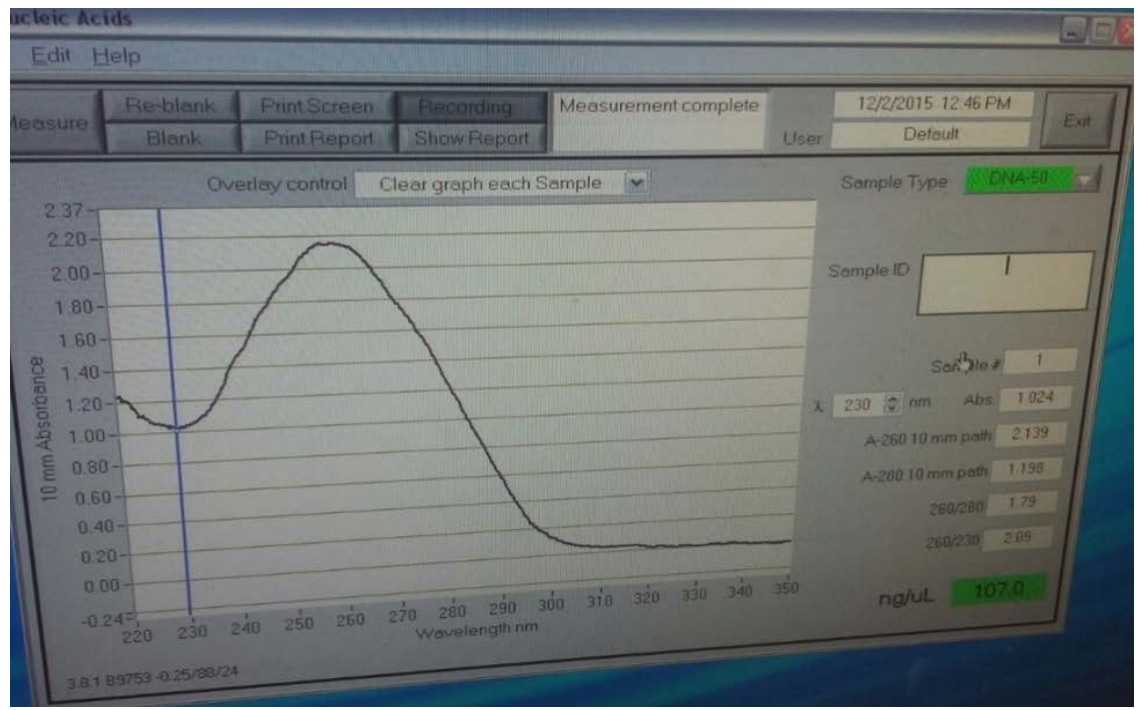

(b)

Figure 1. ( $a$ and $b)$ : concentration of the isolated and purified vector.

$\mu \mathrm{l}$ of culture was added to each of the plates, therefore amount of intact plasmid DNA plated on each plate is calculated as: DNA plated per $\mathrm{ml}=4.5 \times 10^{-2} \times$ $1000=45 \mu \mathrm{g} / \mu \mathrm{l}$.

Transformation efficiency $=\frac{\text { Average number of colonies on LB-AMP plate }}{45 \mu \mathrm{g} / \mu \mathrm{l}}$

$122 \times 8=976$

$45 \mu \mathrm{g} / \mu \mathrm{l}, \geq 21.68 \mu \mathrm{g} / \mu \mathrm{l}$.

\subsection{Analysis of PCR Product by Agarose Gel Electrophoresis}

After doing colony PCR, the amplified samples from the four randomly selected colonies along with positive and negative control were run on $1 \%$ agarose gel and following bands were obtained under UV exposure (Figure 2). 


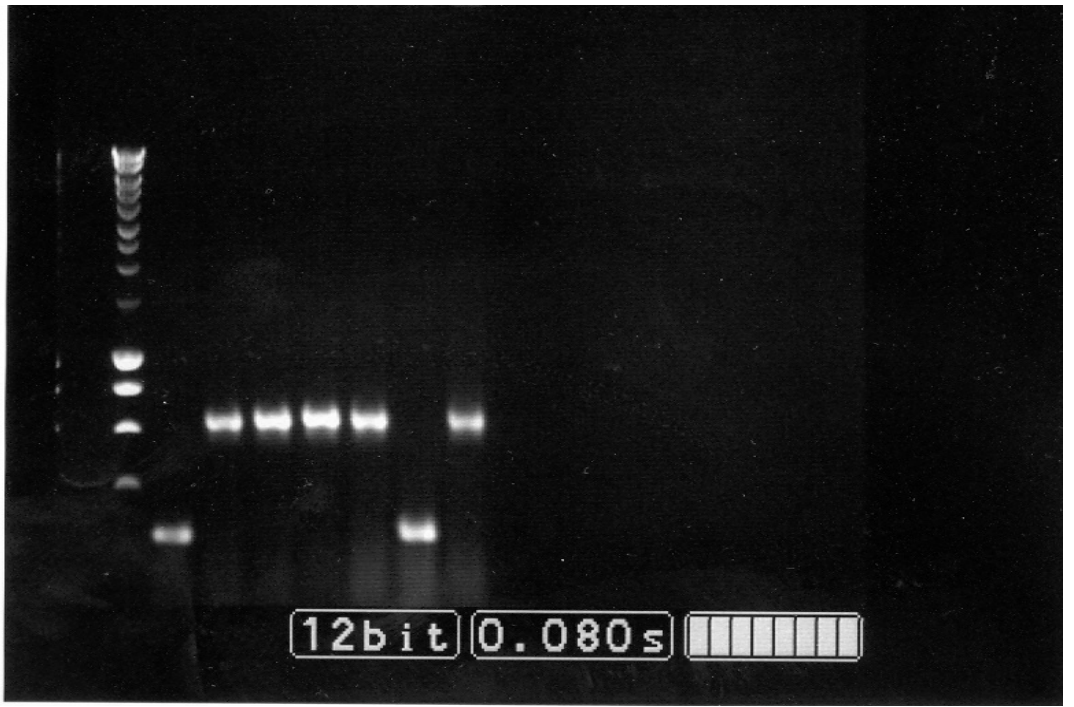

Figure 2. 1\% agarose gel eleectrophorosis product.

\section{SampleMigration $=6.0 \mathrm{~cm}$; RF of sample is 0.76}

Dye migration distance $=7.9 \mathrm{~cm}$

\section{Molecular weight of Nanobody}

Equation of the line $=\mathrm{y}=-2.222 \mathrm{x}+4.431 . \mathrm{X}=0.76$

Therefore, by substitution, $y=(-2.222) \times(0.76)+4.431=2.755$. Hence, Antilog of $2.755=569 \mathrm{bp}$.

\section{Molecular weight of the vector}

\section{Molecular weight of the vector}

Equation of the line $=y=-2.7836 \mathrm{x}+4.5197 ; \mathrm{X}=0.39$, therefore, $\mathrm{y}=-2.8582$ $\times 0.39+4.5197=3.4341$ antilog $3.4341=2717 \mathrm{bp}$.

\section{Discussion}

Plasmid Isolation and determination of its concentration: In order to evaluate and analyze the concentration and purity of DNA, UV spectrophotometer and agarose gel electrophoresis are commonly used (Table 1). Nowadays, plasmid DNA Purification from E. coli by alkaline lysis is based on the differential denaturation of chromosomal and plasmid DNA in order to separate the two [13]. It is lysed with a solution with SDS and $\mathrm{NaOH}$. It permits the analysis by gel electrophoresis of more clones/day/yields plasmid DNA which is pure enough to be digestible by RE. The principle of the method is selective alkaline denaturation of high molecular weight (Table 2 and Table 3) chromosomal DNA while covalently closed circular DNA remains double-stranded [10] [13]. Measurement of the absorbance level between $230 \mathrm{~nm}$ to $320 \mathrm{~nm}$ gives information about both the contaminant and DNA (Figure 2 and Figure 3). Optical density of the plasmid DNA was determined by Nano-Drop spectrophotometer at 260 and 280 $\mathrm{nm}$. Accodingly, concentration of it was found to be $0.0447 \mu \mathrm{g} / \mu \mathrm{l}$. On the other hand, the purity of the plasmid DNA was 1.78 at A260/A280 OD. From in $50 \mathrm{ml}$, we have got $2.235 \mu \mathrm{g}$ plasmid DNA. The purity of our plasmid DNA was deter- 
mined by measuring the OD280 and taking ratio of the two readings: OD260/ $\mathrm{OD} 280=1.91$. A value 1.8 or above indicates that it is adequately pure; on the other hand bellow this implies there is contaminant; impure which may have an effect on restriction digestion.

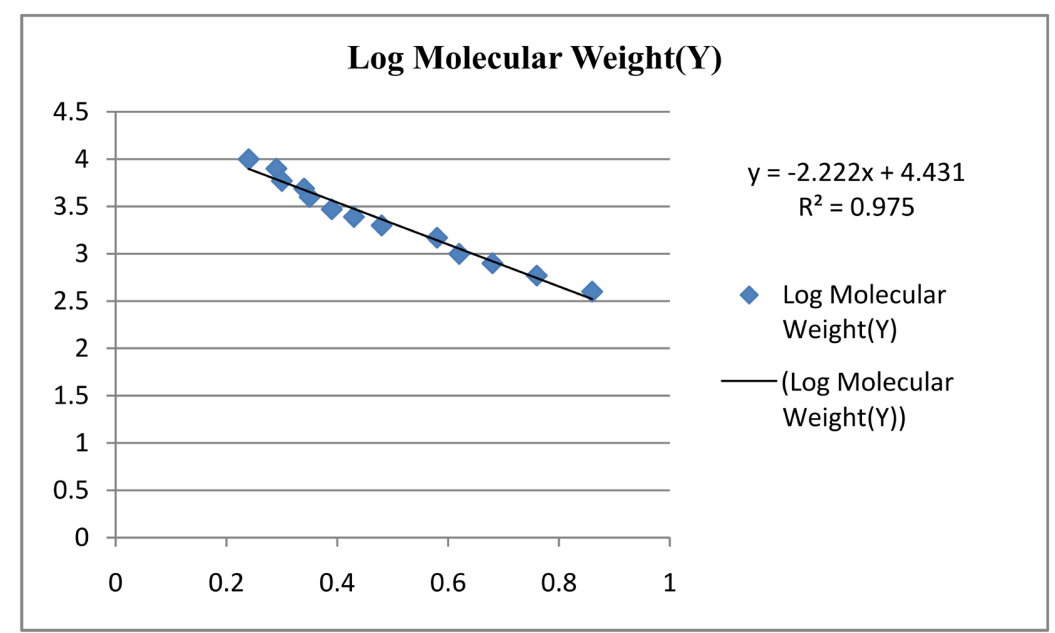

Figure 3. Graph of log of molecular weights versus relative distances for the calculation of molecular weight of the Nanobody.

Table 1. Showing the relative distances migration of Nanobody and log of molecular weight.

\begin{tabular}{cccc}
\hline Molecular size & Distance in unit & Log of MW & Relative distance travelled (Rf) \\
\hline 10,000 & 1.9 & 4.00 & 0.24 \\
8000 & 2.3 & 3.90 & 0.29 \\
6000 & 2.4 & 3.77 & 0.34 \\
5000 & 2.7 & 3.69 & 0.35 \\
4000 & 2.8 & 3.60 & 0.39 \\
3000 & 3.1 & 3.47 & 0.43 \\
2500 & 3.4 & 3.39 & 0.48 \\
2000 & 3.8 & 3.30 & 0.58 \\
1500 & 4.6 & 3.17 & 0.62 \\
1000 & 4.9 & 3.00 & 0.68 \\
800 & 5.4 & 2.90 & 0.76 \\
600 & 6.0 & 2.77 & 0.86 \\
400 & 6.8 & 2.6 & \\
\hline
\end{tabular}

Table 2. Showing the RF and log of molecular weight of Nanobody.

\begin{tabular}{|c|c|c|c|c|c|c|c|c|c|c|c|c|c|}
\hline DNA Marker & 1 & 2 & 3 & 4 & 5 & 6 & 7 & 8 & 9 & 10 & 11 & 12 & 13 \\
\hline $\mathrm{RF}(\mathrm{x})$ & 0.24 & 0.29 & 0.30 & 0.34 & 0.35 & 0.39 & 0.43 & 0.48 & 0.58 & 0.62 & 0.68 & 0.76 & 0.86 \\
\hline $\log$ MWT(Y) & 4.00 & 3.90 & 3.77 & 3.69 & 3.60 & 3.47 & 3.39 & 3.30 & 3.17 & 3.00 & 2.90 & 2.77 & 2.6 \\
\hline MolecularWT (bp) & 10,000 & 8000 & 6000 & 5000 & 4000 & 3000 & 2500 & 2000 & 1500 & 1000 & 800 & 600 & 400 \\
\hline
\end{tabular}


Table 3. Showing the relative distances migration of vecorand log of molecular weight.

\begin{tabular}{cccc}
\hline Molecular size & Distance in unit & Log of MW & Relative distance travelled (Rf) \\
\hline 8000 & 1.5 & 3.90 & 0.24 \\
6000 & 1.7 & 3.77 & 0.27 \\
5000 & 1.8 & 3.69 & 0.29 \\
4000 & 2.1 & 3.60 & 0.34 \\
3000 & 2.4 & 3.47 & 0.39 \\
2500 & 2.5 & 3.39 & 0.40 \\
2000 & 2.6 & 3.30 & 0.41 \\
1500 & 2.9 & 3.17 & 0.47 \\
1000 & 3.4 & 3.00 & 0.55 \\
800 & 3.6 & 2.90 & 0.58 \\
600 & 3.9 & 2.77 & 0.63 \\
400 & 4.4 & 2.6 & 0.71 \\
200 & 4.9 & 2.3 & 0.79 \\
\hline & & & \\
\hline
\end{tabular}

\section{Restriction Endonuclease digestion of Nanobody gene and pHEN6c} plasmid: REs are used to cut double stranded DNA at regions called the restriction site. The concentration and purity of isolated DNA plasmid before digestion was $44.7 \mathrm{ng} / \mu \mathrm{l}$ land 1.78 respectively. The concentration and purity of DNA plasmid after digestion was found to be $107.0 \mathrm{ng} / \mu \mathrm{l}$ and 1.79 respectively (Table 4).

Transformation efficiency: it is efficiency of cells to transform and take up extracellular DNA and express genes to encode, based on the competence of the cells. It can be calculated by dividing the number of successful transformants by the amount of DNA used during a transformation procedure [13]. Cells that have taken up DNA to express genes on the introduced DNA is called transformants [14]. According to Hanahan and Bloom [15], Since E. coli is not naturally transformable, the ability to take up DNA or competency must be induced by chemical methods using divalent and multivalent cations such as calcium, magnesium, manganese, rubidium, or hexamine cobalt. Transformation efficiency is a measure of the amount of cells within the bacterial culture that are able to take up DNA molecules. For some molecular biology projects, such as cloning and subcloning, high transformation efficiency is not critical [16].

In Molecular Biology, electrophoresis is the most commonly used technique to isolate a molecules based on size and electric charge (Figure 4). DNA moves through the pores of the gel through sieving phenomenon. I am used to calculate the molecular weight (Table 4) of nucleic acids [17]. As described on Figure 5, the molecular weight of the Nanobody and vector were 569 and 2717 respectively. 
Table 4. Showing the RF and log of molecular weight of Nanobody.

\begin{tabular}{|c|c|c|c|c|c|c|c|c|c|c|c|c|c|}
\hline No & 1 & 2 & 3 & 4 & 5 & 6 & 7 & 9 & 10 & 10 & 11 & 12 & 13 \\
\hline $\mathrm{RF}(\mathrm{x})$ & 0.24 & 0.27 & 0.29 & 0.34 & 0.39 & 0.4 & 0.41 & 0.47 & 0.55 & 0.58 & 0.63 & 0.71 & 0.79 \\
\hline $\begin{array}{c}\text { Log Vector Molecular } \\
\text { Weight (y) }\end{array}$ & 3.9 & 3.77 & 3.69 & 3.6 & 3.47 & 3.39 & 3.3 & 3.17 & 3 & 2.9 & 2.77 & 2.6 & 2.3 \\
\hline
\end{tabular}

Sample Migration $=2.4 \mathrm{~cm} ; \mathrm{RF}=0.39$. Dye migration distance $=6.2 \mathrm{~cm}$.

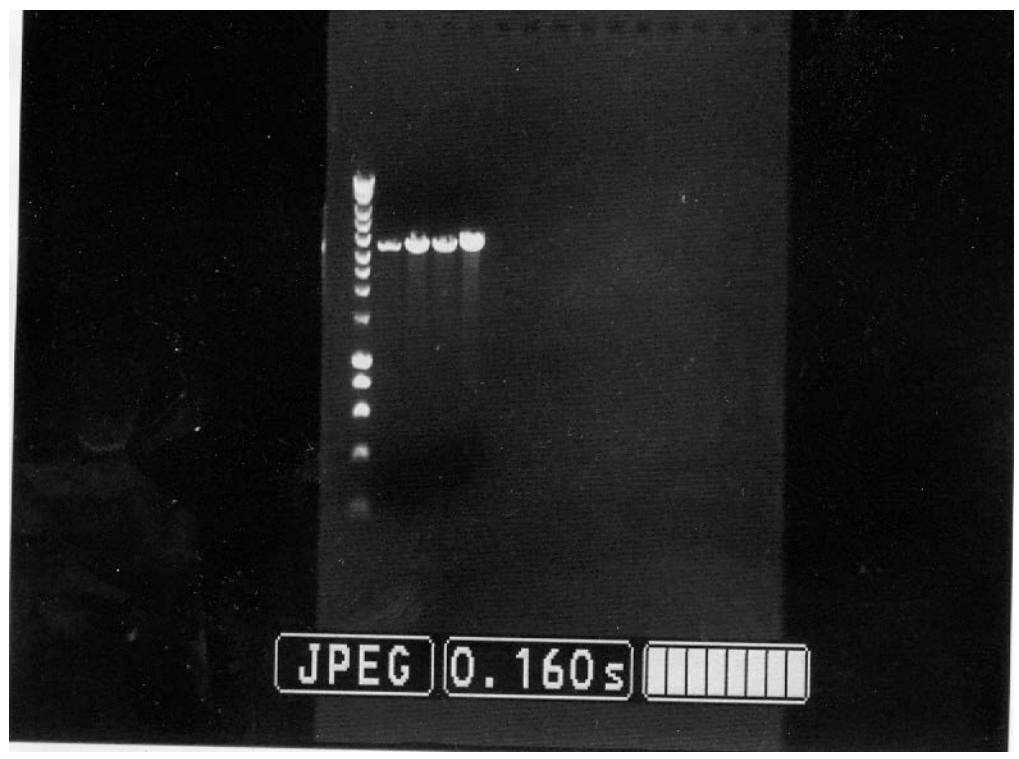

Figure 4. Results of gel electrophoresis showing migration of the vector on agarose gel.

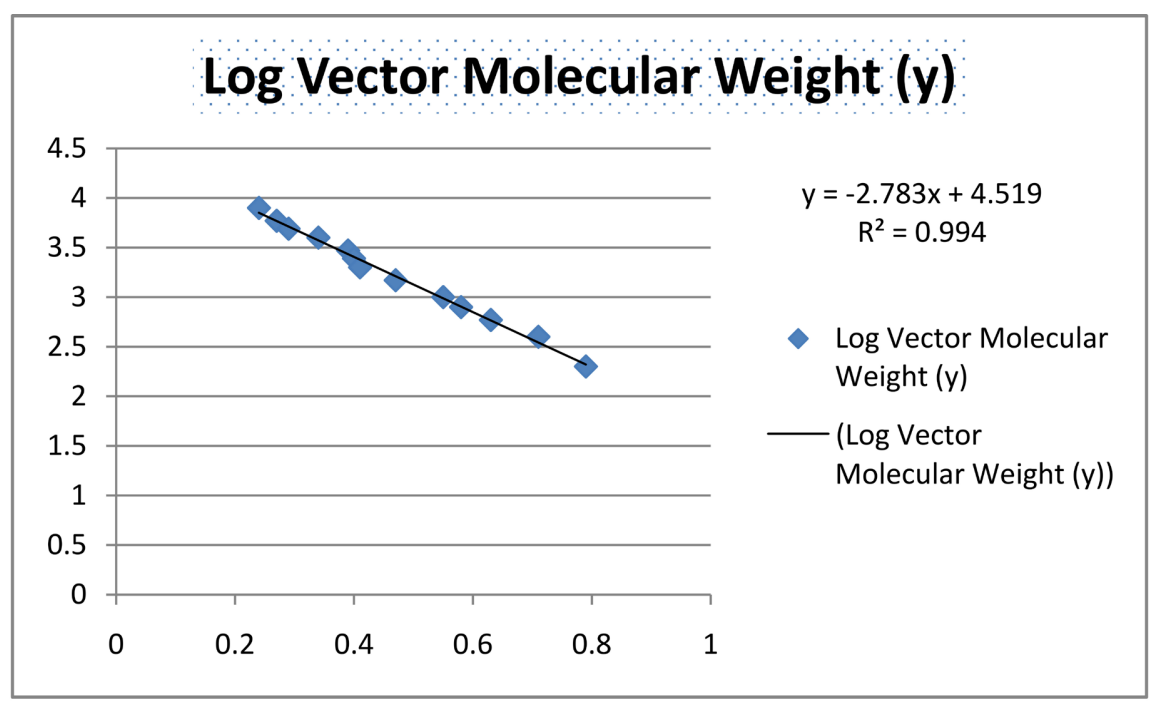

Figure 5. Graph of log of molecular weights versus relative distances for the calculation of molecular weight of thevector.

\section{Conclusions and Recommendations}

Recombinant DNA (rDNA) is formed by several laboratory strategies of genetic recombination to gather together genetic information/code of various multiple 
sources to create genetic sequences the identical overall structures differ only in the nucleotide sequence. Furthermore, it is also referred gene manipulation or genetic engineering, as the original gene is being artificially altered and changed. The gene of interest of AN organism has been placed to others which are distantly related host organism to propagate a defined and relatively small piece of DNA in it. Nowadays there are many techniques to have rDNA which are transformed, page introduction, and non-bacterial transformation. Transformation is the incorporation of gene of interest into a vector, followed by the insertion or transformation of vector into the host like $E$. coli. This is the method we have used when we did the lab practice. On the other hand, non-bacterial transformation, involves similar steps as normal transformation though does not use any bacterial since the DNA or gene of interest is directly injected into the nucleus of the cell being transformed. Finally, in phage introduction, the rDNA is made up by using viral infection rather than bacteria which is called transfection.

\section{Conflicts of Interest}

The author declares no conflicts of interest regarding the publication of this paper.

\section{References}

[1] Russel, P.J. (2005) Genetics: A Molecular Approach. Pearson Education, San Francisco.

[2] Shah, J.M., Ramakrishnan, A.M., Singh, A.K., Ramachandran, S., Unniyampurath, U., Jayshanka, A., Balasundaram, N., Dhanapal1, S., Hyde4 G. and Baskar, R. (2015) Suppression of Different Classes of Somaticmutations in Arabidopsis by VirgeneExpressing Agrobacterium Strains. BMC Plant Biology, 15, 210. https://doi.org/10.1186/s12870-015-0595-1

[3] Rusche, J.R. and Howard-Flanders, P. (1985) Hexamine Cobalt Chloride Promotes Intermolecular Ligation of Blunt end DNA Fragments by T4 DNA Ligase. Nucleic Acids Research, 13, 1997-2008. https://doi.org/10.1093/nar/13.6.1997

[4] Stemmer, W.P., Crameri, A., Ha, K.D., Brennan, T.M. and Heyneker, H.L. (1995) Single-Step Assembly of a Gene and Entire Plasmid from Large Numbers of Oligodeoxyribonucleotides. Gene, 164, 49-53. https://doi.org/10.1016/0378-1119(95)00511-4

[5] Viovy, J.-L. (2000) Electrophoresis of DNA and other Polyelectrolytes: Physical Mechanisms. Reviews of Modern Physics, 72, 813-872. https://doi.org/10.1103/RevModPhys.72.813

[6] Sambrook, J. and Russel, D.W. (2001) Molecular Cloning: A Laboratory Manual. 3rd Edition. Cold Spring Harbor Laboratory Press, Cold Spring Harbor, NY.

[7] Sambroock, J., Fritsche, E.F. and Manniatis, T. (2001) Molecular Cloning: A Laboratory Manual. 3rd Edition. Cold Spring Harbor Laboratory, Cold Spring Harbor, NY.

[8] Steven, A., Baumeister, W., Johnson, L.N. and Perham, R.N. (2016) Molecular Biology of Assemblies and Machines. 1st Edition. Bioscience, New York.

https://doi.org/10.1201/9780429258763

[9] Primrose, S.B. and Twyman, R.M. (2007) Principles of Gene Manipulation and Ge- 
nomics. 7th Edition. Blackwell Publishing, Oxford.

[10] Watson, D.J., Caudy, A.A., Meyers, and Witkowski, R.M. (2007) Recombinant DNA Genes and Genomes-A Short Course. 3rd Edition. W. H. Freeman and Company, Cold Spring Harbor, New York.

[11] Lodish, H., Berk, A., Zipursky, S.L., Matsudaira, P., Baltimore, D. and Darnell, J. (2000) Molecular Cell Biology. 4th Edition. W. H. Freeman, New York. https://www.ncbi.nlm.nih.gov/books/NBK21475/

[12] Brown, T.A. (2008) Gene Cloning \& DNA Analysis. An Introduction. 5th Edition. Blackwell Publishing, Oxford.

[13] Birnboim, H.C. (1983) A Rapid Alkaline Extraction Method for the Isolation of Plasmid DNA. Methods in Enzymology, 100, 243-255. https://doi.org/10.1016/0076-6879(83)00059-2

[14] Maniatis, T., Fritsch, E.F. and Sambrook, J. (1982) Molecular Cloning, a Laboratory Manual. Cold Spring Harbor Laboratory, Cold Spring, NY.

[15] Hanahan, D. and Bloom, F.R. (1996) Mechanisms of DNA Transformation. In: Neidhardt, F.C., Curtiss III, R.C., Ingraham, J.L., Lin, E.C.C., Low, K.B., Magasanik, B., Reznikoff, W.S., Riley, M., Schaechter, M. and Umbarger, H.E., Eds., Escherichia coli and Salmonella Cellular and Molecular Biology, ASM Press, Washington, 24492459.

[16] Tang, X., Nakata, Y., Li, H.O., Zhang, M., Gao, H., Fujita, A., Sakatsume, O., Ohta, T. and Yokoyama, K. (1994) The Optimization of Preparations of Competent Cells for Transformation of E coli. Nucleic Acids Research, 22, 2857-2858. https://doi.org/10.1093/nar/22.14.2857

[17] Berg, J.M., Tymoczko, J.L. and Stryer, L. (2002) Biochemistry. 5th Edition. W. H. Freeman and Company, New York. 